REFLEKSI HUKUM

Jurnal Ilmu Hukum
p-ISSN 2541-4984 | e-ISSN 2541-5417

Volume 2 Nomor 2, April 2018, Halaman 167 - 180

DOI: https://doi.org/10.24246/jrh.2018.v2.i2.p167-180

Open access at: http://ejournal.uksw.edu/refleksihukum Penerbit: Fakultas Hukum Universitas Kristen Satya Wacana

\title{
TERIKATNYA NEGARA DALAM PERJANJIAN INTERNASIONAL
}

\author{
Danel Aditia Situngkir \\ Sekolah Tinggi Bahasa Asing Prayoga \\ Korespondensi: danel@stba-prayoga.ac.id
}

\begin{abstract}
Abstrak
Tulisan ini membahas isu tentang terikatnya negara dalam perjanjian internasional. Semakin kompleksnya hubungan antar subjek hukum internasional membuat kebiasaan internasional tidak lagi dapat dipakai untuk menyelesaikan pelbagai permasalahan yang timbul. Dalam hubungan internasional modern, keberadaan perjanjian internasional merupakan hal yang wajib. Permasalahan yang dibahas dalam tulisan ini adalah peran negara dalam perjanjian internasional dan bagaimana terikatnya negara dalam perjanjian internasional. Kedua permasalahan ini dikaji dengan pendekatan yuridis normatif berdasarkan teori hukum, prinsipprinsip hukum, sumber hukum internasional dan perjanjian internasional. Dari pembahasan disimpulkan bahwa peran negara dalam perjanjian internasional akan mempengaruhi tindakan negara terhadap perjanjian internasional. Terikatnya negara dalam perjanjian internasional diakibatkan oleh tindakan negara dan isi perjanjian internasional. Negara ketiga dapat terikat kepada isi perjanjian internasional apabila norma yang diatur didalamnya merupakan bagian dari jus cogens.
\end{abstract}

Kata kunci: perjanjian internasional, negara, ikatan.

\begin{abstract}
This paper discusses the issue of the binding of the state in international agreements. The more complex the relations between international legal subjects making international customs can no longer be used to resolve the various problems that arise. In modern international relations, the existence of international treaties is mandatory. The issues discussed in this paper are the role of the state in international treaties and how the state is bound in international treaties. Both of these issues are examined with normative juridical approaches based on legal theory, legal principles, international law sources and international agreements. From the discussion it was concluded that the role of the state in international agreements will influence the actions of the state against international agreements. The binding of the state in international agreements is caused by the actions of the state and the contents of international agreements. a third country may be bound by the contents of an international treaty if the norm set forth therein is part of the jus cogens.
\end{abstract}

Keywords: international treaty, state, bond. 


\section{PENDAHULUAN}

Dewasa ini hubungan antar negara (termasuk dengan organisasi internasional) merupakan hal niscaya demi memenuhi kebutuhan dan kepentingan masing-masing negara. Dilihat dari sejarahnya, hubungan antar negara pada zaman dahulu hanya diatur dalam kebiasaan internasional. Seiring dengan perkembangan zaman, berbagai permasalahan yang timbul akibat hubungan tersebut tidak lagi dapat diselesaikan dengan merujuk kepada kebiasaan internasional. Menyadari hal itu, negara-negara dalam menjalin hubungan satu sama lain lalu menuangkannya dalam suatu perjanjian internasional.

Pengaturan secara umum mengenai perjanjian internasional terdapat dalam Konvensi Wina 1969 tentang Hukum Perjanjian Internasional. Konvensi ini dibentuk tanggal 23 Mei 1969 dan mulai berlaku efektif setelah diratifikasi 35 negara sebagaimana diatur dalam Pasal 84, yakni pada 27 Januari $1980 .{ }^{1}$ Menurut Pasal 2 ayat 1 (a) Konvensi Wina 1969:

"treaty means an international agreement concluded between states in written form and governed by international law, whether embodied in a single instrument or in two or more related instruments and whatever its particular designation."

Terdapat banyak sebutan bagi perjanjian internasional, misalnya saja traktat, konvensi dan lain sebagainya. Dalam Black Law's Dictionary definisi perjanjian internasional antara lain:
1. treaty is a compact made between two or more independent nations with a view to the public welfare

2. an agreement, league, or contract between two or more nations or sovereigns, formally signed by commissioners properly authorized, and solemnly ratified by the several sovereigns or the supreme power of each state

3. a treaty is not only a law but also a contract between two nations and must, if possible, be so construed as to give full force and effect to all its parts. ${ }^{2}$

John O'Brian merangkum beberapa prinsip yang menjadi dasar dari traktat atau perjanjian internasional:

1. Muncul diakibatkan persetujuan.

2. Negara yang memberikan persetujuan untuk memberlakukannya sebagaimana yang diinginkan oleh traktat terhadap pihak lain.

3. Dalam hal traktat tersebut mengkodifikasi kebiasaan, maka negara-negara peserta terikat oleh traktat yang menurut prinsipprinsip umum.

4. Dalam hal bukan Negara peserta, maka traktat tetap mengikat berdasar pada alasan kewajiban muncul sebagai akibat dari kebiasaan.

5. Traktat multilateral pada umumnya dibentuk di bawah International Law Commision, yang bertujuan untuk terciptanya pembentukan hukum internasional yang progresif, yang tentunya melibatkan kodifikasi atas hukum kebiasaan. ${ }^{3}$

Nama resminya adalah Vienna Convention on the Law of Treaties 1969.

Henry Campbell Black, Black's Law Dictionary (West Publishing Co. 1968) 1673-1674.

Jawahir Thantowi Iskandar, Hukum Internasional Kontemporer (Refika Aditama 2006) 56-57. 
Terlepas dari bagaimana menyatukan persepsi negara terhadap suatu permasalahan, masalah yang kerap dihadapi dalam penerapan perjanjian internasional yaitu hambatan institusional yang ditimbulkan oleh setiap negara yang diakui memiliki kedaulatan. Atas dasar itu tulisan ini akan membahas tentang kedudukan negara dalam perjanjian internasional dan terikatnya negara pada perjanjian internasional. Terikatnya negara dalam perjanjian internasional, dalam tulisan ini, akan ditinjau dari dua aspek. Pertama, peran negara dalam perjanjian internasional. Kedua, substansi dari perjanjian internasional itu sendiri. Negara bukan pihak/negara ketiga dapat terikat kepada isi perjanjian internasional apabila norma yang diatur di dalamnya merupakan bagian dari jus cogens.

\section{PEMBAHASAN}

\section{Kedudukan Negara dalam Perjanjian Internasional}

Negara merupakan subjek hukum yang terpenting (par excelence) dibanding dengan subjek-subjek hukum internasional yang lainnya. Sebagai subjek hukum internasional negara memiliki hak-hak dan kewajiban menurut hukum internasional. 4

Hak- hak dasar Negara sebagai berikut: 5

a. Hak atas kemerdekaan dan self determination

Pasal 1 ayat 2 Piagam PBB : " to develop friendly relations among nations based on respect for the principle of equal rights and selfdetermination of peoples, and to take other appropriate measures to strengthen universal peace "

Dalam pasal 55 Piagam PBB : "with a view to the creation of conditions of stability and well-being which are necessary for peaceful and friendly relations among nations based on respect for the principle of equal rights and self-determination of peoples...."

Dari ketentuan diatas disimpulkan sebagai hak untuk menciptakan keadaan-keadaan yang tertib dan kemakmuran yang merupakan dasar bagi terciptanya perdamaian dan hubungan antar negara.

b. Hak untuk melaksanakan yurisdiksi terhadap wilayahnya, orang dan benda yang berada di dalam wilayahnya. Merupakan hak yang melekat pada setiap Negara yang merdeka sebagai konsekuensi dari kedaulatan yang dimilikinya.

c. Hak untuk mendapatkan kedudukan hukum yang sama. Hak ini merupakan konsekuensi dari prinsip kedaulatan Negara, meskipun dalam realitanya kondisi suatu Negara berbeda dengan Negara lain, ada Negara kecil, Negara besar, Negara kaya dan Negara miskin.

d. Hak untuk menjalankan pertahanan diri sendiri sesuai atau kolektif (self defense).

\footnotetext{
$4 \quad$ Huala Adolf, Aspek-Aspek Negara Dalam Hukum Internasional (Revisi, Rajagrafindo Persada 2002$) 1$.
}

5 Sefriani, Pengantar Hukum Internasional (Rajagrafindo Persada 2015) 113-133. 
Kewajiban-kewajiban dasar negara sebagai berikut: 6

a. Kewajiban untuk tidak melakukan intervensi terhadap masalahmasalah yang terjadi di Negara lain.

b. Kewajiban untuk tidak menggerakkan pergolakan sipil di Negara lain.

c. Kewajiban untuk memperlakukan semua orang yang berada di wilayahnya dengan memperhatikan HAM.

d. Kewajiban untuk menjaga wilayahnya agar tidak membahayakan perdamaian dan keamanan internasional.

e. Kewajiban untuk menyelesaikan sengketa secara damai.

f. Kewajiban untuk tidak menggunakan kekuatan dan ancaman senjata.

g. Kewajiban untuk tidak membantu terlaksananya penggunaan kekuatan dan ancaman senjata.

h. Kewajiban untuk tidak mengakui wilayah-wilayah yang diperoleh melalui cara-cara kekerasan.

i. Kewajiban untuk melaksanakan kewajiban internasional dengan itikad baik.

j. Kewajiban untuk mengadakan hubungan internasional dengan Negara- negara lain sesuai hukum internasional.

Jika melihat paparan mengenai hak dan kewajiban dasar negara diatas, dapat disimpulkan terlepas dari ada atau tidaknya perjanjian internasional pada prinsipnya negara-negara di dunia memiliki hak dan kewajiban dasar yang harus dipedomani demi terciptanya hidup berdampingan secara damai (peaceful co-existence).

Perjanjian internasional merupakan salah satu rujukan bagi negaranegara atau subjek hukum internasional lain untuk menyelesaikan berbagai permasalah-an yang terjadi dalam hubungan internasional selain kebiasaan internasional, prinsip hukum umum, yurisprudensi dan pendapat para sarjana terkemuka. Perjanjian internasional adalah perjanjian yang diadakan diantara anggota masyarakat bangsa-bangsa dan bertujuan untuk mengakibatkan suatu hukum tertentu menjadi berlaku. Perjanjian internasional tertulis ini menimbulkan kewajiban-kewajiban bagi para pihak di dalamnya. ${ }^{7}$

Berdasarkan definisi tersebut bahwa subjek hukum internasional yang mengadakan perjanjian adalah anggota masyarakat bangsa-bangsa, termasuk juga lembaga internasional dan negara. Dari definisi-definisi tersebut dapat disimpulkan mengenai ciri-ciri perjanjian internasional bahwa pihak-pihak yang mengadakan perjanjian saling menyetujui antara pihak-pihak yang dapat menimbulkan hak dan kewajiban dalam bidang internasional. 8

Sama halnya dengan perjanjian pada umumnya, negara dalam suatu perjanjian internasional memiliki peran yang ditentukan sendiri oleh negara tersebut. Konvensi Wina 196 dan

Ibid., 138.

J.G Starke, Pengantar Hukum Internasional (Sinar Grafika 2004) 117.

Arfiana Novera Meria Utama, Dasar-Dasar Hukum Kontrak dan Arbitrase (Tunggal Mandiri Publishing 2014) 12. 
Konvensi Wina 1986 membagi peran negara dalam perjanjian internasional kedalam 2 (dua) kelompok:

1. Negara Pihak

Pengertian negara pihak (party) dapat dilihat dalam Pasal 2 (g) Konvensi Wina 1969: "Party means a Statewhich has consented to be bound by the treaty and for which the treaty is in force" Sedangkan pengertian pihak (party) juga ditemukan dalam pasal 2 (g) Konvensi Wina 1986: "party" means a State or an international organization which has consented to be bound by the treaty and for which the treaty is in force; Melihat dari pengertian diatas, maka Negara pihak adalah Negara yang menyatakan terikat pada ketentuan yang diatur dalam perjanjian internasional.

2. Negara Bukan Pihak

Pengertian negara bukan pihak (third state) dapat dilihat dalam Pasal 2 (h) Konvensi Wina 1969: "third state" means a State not a party to the treaty. Sedangkan pengertian Negara bukan pihak (third state) dalam pasal 2 (h) Konvensi Wina 1986: "third state" and "third organization" mean respectively: a State, or an international organization, not a party to the treaty;

Negara bukan peserta merupakan negara yang tidak terlibat dalam perjanjian internasional, maka dari itu sebuah perjanjian tidak menciptakan baik kewajiban atau hak untuk negara ketiga tanpa persetujuan.
Peran sebagai negara pihak maupun sebagai bukan negara pihak akan melahirkan hak dan kewajiban bagi negara. Misalnya negara yang terlibat dalam perjanjian internasional biasanya akan menyusun perjanjian yang akan dibuat, sebagaimana diatur dalam Pasal 7 Konvensi Wina 1969 Perjanjian dapat disusun antara Negara atau pemerintahan atau kepala Negara atau instansi pemerintah yang memiliki kewenangan yang diberikan oleh negara yang mengutusnya.

Tugas dari para perwakilan Negara tersebut adalah "purpose of adopting or authenticating the text of a treaty or for the purpose of expressing the consent of the State to be bound by a treaty". Dengan melihat tugas dari para pejabat tersebut dalam mewakili Negara tersebut dapat kita lihat gambaran umum mengenai proses pembentukan perjanjian internasional:

1. Adoption of the text

Adopsi teks perjanjian adalah bentuk persetujuan semua negara yang terlibat dalam penyusunan perjanjian internasional, untuk konferensi internasional proses adopsi teks perjanjian dapat dilakukan jika tercapai dua pertiga dari negara yang terlibat, kecuali ditentukan lain oleh konferensi tersebut.

2. Authentication of the text

Teks perjanjian ini ditetapkan sebagai otentik dan definitif dengan prosedur seperti dapat diberikan dalam teks atau disepakati oleh negara berpartisipasi dalam pembuatannya perjanjian tersebut.

3. Consent to be bound 
Untuk terikat dengan sebuah perjanjian, persetujuan dari Negara untuk terikat pada perjanjian dapat dinyatakan dengan tandatangan, pertukaran instrumen, ratifikasi, penerimaan, persetujuan atau aksesi, atau dengan cara lain yang disepakati.

Bentuk tindakan yang menyatakan suatu Negara terikat pada perjanjian internasional, yaitu:

1. Penandatanganan (Signatured)

Persetujuan dari Negara untuk terikat oleh perjanjian dinyatakan oleh tanda tangan perwakilan apabila:

a. Perjanjian menyatakan bahwa tanda tangan akan memiliki efek mengikatnya perjanjian.

b. Jika tidak ditetapkan, negara yang terlibat negosiasi sepakat bahwa tanda tangan harus memiliki efek terikatnya negara dalam perjanjian internasional.

c. Efek tanda tangan muncul dari kekuatan penuh perwakilannya.

2. Pertukaran instrumen-instrumen (exchange of instruments constituting a treaty) :

Persetujuan dari Negara untuk terikat oleh perjanjian didasari oleh instrumen yang dipertukarkan apabila instrumen menetapkan bahwa pertukaran tersebut akan memiliki efek mengikatnya perjanjian internasional atau jika negara-negara itu sepakat bahwa pertukaran instrumen dinyatakan sebagai syarat mengikatnya perjanjian internasional.

3. Ratification, acceptance or approval
Persetujuan untuk terikat dengan sebuah perjanjian yang diungkapkan oleh ratifikasi, penerimaan atau persetujuan.

Persetujuan dari negara untuk terikat dengan perjanjian yang diungkapkan oleh ratifikasi ketika:

a. Perjanjian menentukan demikian.

b. Negara yang bernegosiasi sepakat bahwa perjanjian harus diratifikasi.

c. Wakil dari Negara telah menandatangani perjanjian untuk subyek ratifikasi.

d. Niat Negara untuk menandatangani perjanjian tunduk pada ratifikasi muncul dari kekuatan penuh perwakilannya atau diungkapkan selama negosiasi.

Persetujuan dari Negara untuk terikat oleh perjanjian dinyatakan oleh penerimaan atau persetujuan di bawah kondisi serupa dengan yang berlaku untuk ratifikasi.

Lalu kapan dimulai berlakunya suatu perjanjian internasional? Mulai berlakunya perjanjian internasional biasanya disebut "entry into force". Setelah semua negara yang terlibat dalam proses pembuatan perjanjian serta telah mengikatkan diri dalam perjanjian internasional tersebut dalam bentuk penandatanganan oleh perwakilan negara yang ditunjuk, maka apabila ditentukan oleh perjanjian itu sendiri kapan klausul yang terakhir yang harus dipenuhi sebelum perjanjian dinyatakan mulai berlaku adalah proses penyerahan ratifikasi kepada badan/ lembaga yang ditunjuk untuk menerima hasil ratifikasi tersebut. Apabila seluruh kondisi yang dipersyaratkan telah 
dipenuhi maka sejak itu pula perjanjian internasional dinyatakan berlaku. Misalnya untuk Konvensi Wina 1969 tentang Perjanjian Internasional sebagaimana diatur dalam Pasal 84, perjanjian baru berlaku efektif setelah hari ketigapuluh setelah tanggal penyerahan instrumen ratifikasi atau aksesi oleh tigapuluh lima negara. Konvensi ini baru mulai berlaku 27 January 1980, artinya butuh waktu sekitar 11 tahun setelah finalisasi dokumen perjanjian (23 Mei 1969) baru konvensi ini dinyatakan mulai berlaku.

Untuk negara bukan pihak sebagai kaidah umum, suatu perjanjian internasional tidak boleh membebankan kewajiban atau hak kepada negara pihak ketiga tanpa ada persetujuan dari mereka (Pasal 34 konvensi Wina 1969). Pada prakteknya diwaktu yang lampau prinsip ini memang ditegaskan dalam perjanjian internasional. Prinsip umum ini dalam dinyatakan dalam dalil latin "pacta tertiis nec nocent nec prosunt" mendapat dukungan dalam praktek negara-negara, dalam keputusankeputusan pengadilan. Misalnya dalam German Interest in Polish Upper Silesia Case, dimana Permanent Court of International mengamati bahwa perjanjian hanya menciptakan hukum antara Negara-negara yang menjadi pihak dalam perjanjian itu, jika terdapat keraguan, tidak ada hak yang dapat disimpulkan dari dalam mendukung Negara ketiga. ${ }^{9}$

Prinsip umum ini sejalan dengan asas Pacta Sunt Servanda yang diakui oleh negara-negara beradab di dunia dalam kerangka hubungan internasional. Prinsip ini diakui universal. Schmitthof dan juga Goldstajn menganggap prinsip/asas ini (beserta prinsip kebebasan berkontrak) sebagai prinsip yang penting. Pengakuan dalam sistim hukum di dunia tidak terlalu sulit untuk menemukannya. Bahkan negaranegara di dunia memasukkan ketentuan ini dalam peraturan perundangan nasionalnya. 10

Grotius mengatakan bahwa diantara asas-asas hukum alam yang melandasi sistem hukum internasional, pacta sunt servanda merupakan asas paling fundamental. Pacta sunt servanda yang merupakan bagian dari hukum kodrat yang menjadi dasar bagi konsensus. Anzilotti penganut aliran dualisme berkebangsaan Italia menguatkan pandangan Grotius dan meletakan dasar daya ikat hukum internasional pada asas pacta sunt servanda. ${ }^{11}$ Alasan paling fundamental yang menguatkan asas ini dalam kaitan hubungan internasional karena adanya prinsip-prinsip dasar kedaulatan dan kemerdekaan negara-negara, yang mengandaikan bahwa negara harus menyetujui peraturan sebelum mereka dapat terikat terhadap peraturan tersebut.

\section{Terikatnya Negara Pada Perjanjian Internasional}

Perjanjian internasional pada
prinsipnya timbul karena ada
kebutuhan untuk mengatur hubungan

9 Ugo Villani, 'The Security Council's Authorization of Enforcement Action by Regional Organization' (2002) 6 Max Planck Yearbook of United Nations Law 535, 538-539.

10 Huala Adolf, Op.Cit., 25-26.

11 Yudha Bhakti Ardhiwisastra, Hukum Internasional (Alumni 2003) 72. 
antara subjek hukum internasional. Menurut hukum internasional dewasa ini setiap negara mempunyai kemampuan mengadakan perjanjian internasional.

Beberapa teori hukum telah menjelaskan hakikat mengikatnya kontrak, diantaranya: ${ }^{12}$

1. Teori Kehendak (the will theory)

Menerangkan bahwa suatu kesepakatan mengikat karena memang merupakan keinginan para pihak.

2. Teori Persetujuan (the bargain theory)

Merupakan pengingkaran dari teori kehendak, menurut teori ini kontrak bukan kehendak para pihak tetapi persetujuan para pihak.

3. Teori kesetaraan (the equivalent theory)

Menurut teori ini para pihak dalam kesepakatan itu telah memberikan kesetaraan (kesamaan para pihak).

4. Teori kerugian (the injurious-reliance theory)

Menyatakan bahwa kesepakatan mengikat karena para pihak telah menyatakan diri untuk mengandalkan pihak yang menerima janji dengan akibat adanya kerugian.

Dari beberapa teori yang dikemukakan tersebut, pada prinsipnya baik teori kehendak, persetujuan, kesetaraan dan kerugian pada masanya sangat relevan, terlebih jika kita berbicara tentang subjek hukum internasional yaitu negara. Hal ini dipertegas dengan prinsip-prinsip hukum umum yang diakui oleh negaranegara berdaulat tentang perjanjian internasional diantaranya prinsip pacta sunt servanda, prinsip itikad baik dan prinsip timbal balik-reprositas.

Dengan berpijak pada teori dan prinsip umum tersebut kemudian kita akan melihat bagaimana terikatnya negara pada perjanjian internasional dalam realitas hubungan internasional. Konvensi Wina 1969 tentang Perjanjian Internasional telah memberikan pijakan dasar tentang norma dalam perjanjian internasional. Keunikan negara dengan kedaulatannya menjadi karakteristik tersendiri yang biasa menjadi sangat "sensitif" yang akhirnya berujung pada sebutan "quacy of law" bagi hukum internasional.

Untuk melihat terikatnya negara pada perjanjian internasional, maka penulis mencoba melihat dari dua aspek. Pertama, peran negara dalam perjanjian yang dilihat dari tindakan negara terhadap perjanjian tersebut. Kedua, substansi dari perjanjian internasional tersebut.

Berdasarkan peran negara tersebut dapat dikatakan suatu negara dikatakan terikat pada perjanjian internasional merupakan kehendak dari negara tersebut untuk terikat dalam kapasitas sebagai negara pihak. Ketika negara bertindak sebagai negara pihak artinya negara siap dengan segala hak dan kewajiban yang dibebankan sesuai dengan perjanjian internasional. Tindakan negara merupakan bentuk penghargaan atas kedaulatan negara dimana negara bebas untuk menentukan sendiri tindakan yang diambilnya.

12 Huala Adolf, Dasar-Dasar Hukum Kontrak Internasional (Refika Aditama 2006) 18. 
Lalu kemudian apakah suatu perjanjian internasional dapat mengikat negara bukan pihak? International Law Commision menjelaskan bahwa dua kondisi yang harus dipenuhi sebelum negara bukan pihak dapat dianggap terikat oleh ketentuan dari perjanjian yaitu:

1. Harus ada keinginan dari negara pihak dalam perjanjian harus berniat ketentuan tersebut menjadi sarana membangun suatu kewajiban bagi Negara bukan pihak dalam perjanjian internasional tersebut.

2. Negara ketiga harus menyatakan tegas persetujuan untuk terikat oleh kewajiban secara tertulis. ${ }^{13}$

Adapun penciptaan hak, International Law Commision mempertimbangkan 2 (dua) kondisi yang harus dipenuhi agar hak timbul bagi negara bukan peserta dari suatu ketentuan perjanjian internasional, yaitu:

1. Harus ada niat para pihak agar sesuai ketentuan hak untuk keadaan yang bersangkutan memberikan hak bagi negara peserta.

2. Persetujuan dari negara penerima. Pertanyaannya mungkin ditimbulkan apakah benar dibuat oleh perjanjian atau tindakan penerima negara dari penerimaan. ${ }^{14}$

Dalam pasal 34 Konvensi Wina 1969, perjanjian tidak bisa memaksakan hak dan kewajiban pada negara-negara bukan peserta dan ini ditekankan oleh International Law Commision (ILC) selama musyawarah sebelum Konferensi Wina. Pengecualian utama untuk hal ini adalah dimana ketentuan-ketentuan dari perjanjian tersebut telah masuk ke dalam hukum kebiasaan internasional. Dalam kasus seperti itu, semua negara akan terikat, terlepas dari apakah mereka telah menjadi negara pihak dalam perjanjian asli atau tidak. Misalnya saja tentang hukum kebiasaan tentang hukum perang yang diangkat dalam Konvensi Jenewa 1949. Dengan demikian dapat disimpulkan, dalam kasus kewajiban yang timbul dari perjanjian, tiga kondisi yang harus dipenuhi:

1. Dengan persetujuan negara bukan peserta, yang mengungkapkan pengakuan terhadap kewajiban yang diberikan oleh perjanjian.

2. Bentuk tertulis dari suatu persetujuan. Pasal 34-37 (Pasal 37 termasuk dalam kategori yang sama seperti Pasal 35-36, karena menyangkut yaitu pencabutan atau modifikasi kewajiban atau hak-hak negara ketiga, atau organisasi yang timbul berdasarkan Pasal 35 dan 36). Pihak dalam perjanjian mengungkapkan keinginan mereka untuk menciptakan baik hak atau kewajiban negara (atau organisasi) yang bukan merupakan pihak dalam perjanjian.

3. Ketika perjanjian menjadi mengikat negara-negara ketiga melalui mekanisme hukum kebiasaan

13 Malgosia Fitzmaurice, 'Third Parties and the Law of Treaties' (2002) 6 Max Planck Yearbook of United Nations Law 37, 37.

14 Ibid. 
internasional sesuai dengan pasal 38.15

Paparan di atas juga memberikan penekanan pada persetujuan dari negara bukan pihak untuk menerima hak dan kewajiban yang diberikan kepadanya dalam perjanjian internasional.

Isi perjanjian internasional pada umumnya diklasifikasikan menjadi dua, yaitu treaty contract dan law-making treaty. Treaty contract yaitu perjanjian yang hanya menimbulkan akibat hukum yakni hak dan kewajiban kepada para pihak yang mengadakan perjanjian itu, misalnya perjanjian perbatasan antar negara. Law-making treaties yaitu perjanjian yang meletakkan ketentuan dan kaidah hukum bagi masyarakat internasional secara keseluruhan, misalnya konvensi hukum laut. 16 Jika dilihat dari isi dari perjanjian internasional itu sendiri, ada kemungkinan suatu perjanjian internasional memberikan hak dan kewajiban tertentu yang dinyatakan secara eksplisit dalam pasal-pasal perjanjian. Beberapa contoh perjanjian international yang memberikan hak atau kewajiban kepada negara bukan pihak diantaranya:

1. Piagam Perserikatan BangsaBangsa

Pasal 6 ayat 1 dikatakan negaranegara bukan anggota Perserikatan Bangsa-bangsa bertindak dengan prinsip-prinsip ini apabila dianggap perlu demi perdamaian internasional.
2. Deklarasi Universal Hak-Hak Asasi Manusia

Dalam Deklarasi yang diterima dan diumumkan oleh Majelis Umum PBB pada tanggal 10 Desember 1948 melalui resolusi 217 A (III) ini frasa yang dipakai adalah setiap orang. Dengan demikian ini dapat dimaknai sebagai setiap orang yang merupakan warga negara pada negara peserta maupun negara bukan peserta dalam deklarasi tersebut maupun piagam $\mathrm{PBB}$, karena deklarasi ini dipelopori oleh PBB.

3. Konvensi Jenewa tahun 1949 tentang perbaikan keadaan anggota angkatan perang yang luka dan sakit di medan pertempuran darat. Dalam Pasal 2 konvensi ini diatur meskipun salah satu dari negaranegara dalam pertikaian mungkin bukan peserta Konvensi ini, negaranegara yang menjadi peserta Konvensi ini akan sama tetap terikat olehnya di dalam hubungan antara mereka. Mereka selanjutnya terikat oleh Konvensi ini dalam hubungan dengan Negara bukan peserta, apabila Negara yang tersebut kemudian ini menerima dan melaksanakan ketentuanketentuan Konvensi ini.

4. Konvensi Hukum Laut

Dalam konvensi hukum laut 1982 dipakai frasa "every state" ini diartikan setiap negara, bisa negara yang menjadi pihak dalam perjanjian international tersebut maupun negara yang bukan menjadi pihak misalnya: Hak untuk

15 Ibid., 57.

16 Mochtar Kusumaatmadja \& Etty R. Agoes, Pengantar Hukum Internasional (Alumni 2003) 122. 
menetapkan lebar laut teritorial 12 mil laut dan semua kapal laut dan kapal udara baik negara peserta maupun negara ketiga. ${ }^{17}$

Negara ketiga atau negara bukan pihak dapat terikat pada isi dari perjanjian internasional apabila ketentuan dalam perjanjian internasional tersebut merupakan bagian dari jus cogens. Jus Cogens yaitu serangkaian prinsip atau norma yang tidak dapat diubah (peremptory norms) yang tidak boleh diabaikan, dan yang karenanya dapat berlaku untuk membatalkan suatu traktat atau perjanjian antar negara-negara dalam hal perjanjian atau traktat itu tidak sesuai dengan salah satu prinsip atau norma tersebut.

Dalam Pasal 53 Konvensi Wina 1969 :

" a treaty is void if, at the time of its conclusion, it conflicts with a peremptory norm of general international law. For the purposes of the present Convention, a peremptory norm of general international law is a norm accepted and recognized by the international community of States as a whole as a norm from which no derogation is permitted and which can be modified only by a subsequent norm of general international law having the same character".

Melihat definisi umum dari jus cogens dalam Konvensi Wina tersebut, dapat diidentifikasi prasyarat yang diperlukan untuk norma dalam hukum internasional untuk menjadi norma jus cogens, antara lain: ${ }^{18}$
1. Merupakan norma dasar hukum internasional

Norma dasar hukum internasional umum adalah hukum internasional yang mengikat sebagian besar negara. Norma dasar dalam hukum internasional merupakan hukum yang mengatur masyarakat internasional pada umumnya, dimana cakupannya lebih luas dari hukum kebiasaan internasional. Norma dasar ini berbeda dengan hukum internasional regional, yang hanya mengikat negara dari wilayah geografis yang diidentifikasi dan hukum internasional tertentu yang hanya mengikat beberapa negara.

2. Norma harus diterima dan diakui oleh komunitas internasional secara keseluruhan

Penerimaan dan pengakuan oleh masyarakat internasional dapat baik yang tertulis maupun tidak tertulis. Sebelum norma dapat dianggap sebagai norma jus cogens, norma tersebut harus diterima dan diakui oleh komunitas internasional secara keseluruhan, dalam beberapa hal proses pembentukannya menyerupai hukum kebiasaan internasional.

3. Norma diangkat dari prinsip-prinsip hukum umum yang diakui bangsabangsa beradab.

Secara umum norma jus cogens dapat ditarik dari sumber hukum internasional sebagai berikut: ${ }^{19}$

1. Perjanjian bersifat universal.

17 Danel Aditia Situngkir, 'Asas Pacta Sunt Servanda dalam Penegakan Hukum Pidana Internasional' (2018) 3 Jurnal Cendikia Hukum 153, 157.

18 Rafael Nieto Navia, 'International Peremptory Norms (Jus Cogens) and International Humanitarian Law' 238-240 <www.dphu.org/uploads/attachements/books/books_4008_0.pdf> accessed 10 January 2018.

Ibid. 
Pada dasarnya perjanjian tidak mengikat negara bukan peserta tanpa persetujuan mereka. Pengecualian untuk prinsip ini adalah jika konvensi atau perjanjian dibuat untuk tujuan yang lebih penting. Jika perjanjian atau konvensi hanya mengatur norma yang ada yang sudah mengikat pada negara sebagai hukum kebiasaan internasional, negara bukan peserta pada perjanjian tersebut mungkin tetap terikat oleh ketentuan yang relevan prinsip hukum umum. Demikian pula, jika ketentuan perjanjian atau konvensi tersebut memenuhi kriteria lain untuk diakui sebagai jus cogens, negara bukan peserta perjanjian juga akan terikat dengan persyaratan dalam perjanjian.

2. Kebiasaan internasional.

Kebiasaan Internasional didefinisikan sebagai bukti praktik umum yang diterima sebagai hukum. Selama bertahun-tahun proses kodifikasi hukum internasional oleh International Law Commision selama bertahun-tahun hukum internasional berasal dari kebiasaan internasional. Banyak yang menyebutkan bahwa perjanjian umum sebenarnya hanya kodifikasi aturan hukum kebiasaan yang sudah ada. Penulis tertentu mengatakan norma jus cogens dapat ditemukan dalam kebiasaan internasional. Dalam perjanjian yang berisikan refleksi dari hukum kebiasaan maka akan mengikat Negara bukan peserta, bukan karena ketentuan dalam perjanjian tersebut, namun karena hal tersebut ditegaskan dalam aturan hukum kebiasaan internasional. Demikian pula, Negara bukan peserta dapat menerima ketentuan dalam perjanjian tertentu dapat menghasilkan hukum kebiasaan, selalu tergantung pada sifat perjanjiannya, jumlah pihak yang terlibat dan faktor lain yang relevan.

\section{PENUTUP}

Dari pembahasan diatas maka dapat disimpulkan bahwa negara dapat berperan sebagai negara pihak atau negara bukan pihak dalam perjanjian internasional dan peran tersebut akan mempengaruhi tindakan negara terhadap perjanjian internasional tersebut. Terikatnya negara dalam perjanjian internasional dapat dilihat dari dua aspek yang pertama dari peran negara dalam perjanjian internasional dan yang kedua dari substansi dari perjanjian internasional itu sendiri. Negara bukan pihak/negara ketiga dapat terikat kepada isi perjanjian internasional apabila norma yang diatur didalamnya merupakan bagian dari jus cogens.

\section{DAFTAR BACAAN}

\section{Buku}

Adolf, Huala, Aspek-Aspek Negara Dalam Hukum Internasional (Revisi, Rajagrafindo Persada 2002). , Dasar-Dasar Hukum Kontrak Internasional (Refika Aditama 2006).

Ardhiwisastra, Yudha Bhakti, Hukum Internasional (Alumni 2003). 
Iskandar, Jawahir Thantowi, Hukum Internasional Kontemporer (Refika Aditama 2006).

Kusumaatmadja, Mochtar, \& Etty R. Agoes, Pengantar Hukum Internasional (Alumni 2003).

Sefriani, Pengantar Hukum Internasional (Rajagrafindo Persada 2015).

Starke, J.G., Pengantar Hukum Internasional (Sinar Grafika 2004).

Utama, Arfiana Novera Meria, DasarDasar Hukum Kontrak dan Arbitrase (Tunggal Mandiri Publishing 2014).

\section{Artikel Jurnal}

Fitzmaurice, Malgosia, Third Parties and the Law of Treaties' (2002) 6 Max Planck Yearbook of United Nations Law 37.

Navia, Rafael Nieto, 'International Peremptory Norms (Jus Cogens) and International Humanitarian Law' <www.dphu.org/uploads/attachem ents/books/books_4008_0.pdf> accessed 10 January 2018.

Situngkir, Danel Aditia, 'Asas Pacta Sunt Servanda dalam Penegakan Hukum Pidana Internasional' (2018) 3 Jurnal Cendikia Hukum 153.

Villani, Ugo, 'The Security Council's Authorization of Enforcement Action by Regional Organization' (2002) 6 Max Planck Yearbook of United Nations Law 535.

\section{Konvensi- Konvensi Internasional}

United Nations, 'Vienna Convention on the Law of Treaties 1969', Treaty series (1969). 
